which ordinary citizens can and do understand and contribute to solving the problems of our complex technological world. Shortly before his accident, he had returned to teaching from a year's sabbatical leave. His activities during that year show Bud at his best as a scholar, teacher, and political activist.

He was one of four eminent scholars invited by Miami University $(\mathrm{OH})$ to lecture and teach as part of its year-long "Latin American Celebration." Later he was also invited to present a paper and teach Dutch graduate students and scholars associated with the Centre for Latin American Research and Documentation (CEDLA) in Amsterdam. He wrote articles and book reviews for Environmental Education, Environmental Ethics, and the LASA Forum.

Making use of his long involvement with Costa Rica, he videotaped interviews with campesinos who have developed methods of fishing and farming that are productive and environmentally sustainable. He was completing a video documentary and a book on this subject at the time of his death.

As a result of these experiences with the campesinos, Bud, always an activist as well as a scholar, became wholeheartedly engaged in the "Responsible Coffee Campaign." This campaign is an effort by environmentalists and academics to encourage consumers to buy coffee grown under environmentally friendly conditions on small family farms, rather than from coffee plantations with their international, or corporate, ownership and heavy use of pesticides.

Beginning in 1966, Bud Kenworthy was a member of the faculty of Cornell University, where he taught Latin American politics. From 198287 , he served as director of undergraduate studies for Cornell's government department, a post which meant overseeing the teaching and advising of what was usually the largest single contingent of student majors at the university. He is remembered by his colleagues at Cornell for his insistence that teaching and advising undergraduates be a priority, even at a university famed for its research and graduate programs.
Bud Kenworthy's close relationship with students became critically important during the student unrest that troubled Cornell in the $1960 \mathrm{~s}$. In 1969, he addressed a gathering of 4,000 students whose leaders were urging violent tactics. Bud, known to the students as a young and sympathetic professor, cautioned the students to be "rational radicals." His influence prevailed.

Bud was first invited to Whitman College in 1991 to serve as the Arnold Distinguished Visiting Professor, a one-year appointment. During that year, he and his wife, Cynthia, grew to love the sere beauty of eastern Washington. Bud also appreciated the opportunity to concentrate on undergraduate teaching at a respected liberal arts college. He returned to Whitman as a full-time faculty member in 1992.

At Whitman, Bud taught courses in Latin American and comparative politics, ecology and development, private and public leadership, and grass-roots activism. Whitman College President Thomas Cronin eulogized him as an "enormously creative and dedicated professor. $\mathrm{He}$ had a major influence on his students here, and he will be greatly missed."

Bud Kenworthy is survived by his wife, daughter, Lauren Kenworthy, and grandsons, Byron and Jesse Kenworthy Schaeffer.

Mary T. Hanna

Whitman College (WA)

\section{Richard Carlton Snyder}

With the passing of Dick Snyder at age 81 on December 9, 1997, in Scottsdale. Arizona, after a brief illness, political science lost one of the most creative and selffess scholarteacher-leader of the post-WWII era. Early in his career, he committed himself to the professional development of political science in the context of other social sciences and professions as a contributor to continuous improvement of individual and public decision-making in democratic societies.

Dick's concerns and commitments characteristically extended far beyond his personal interest and made him an exemplar of the scholarly teacher-leader. Educated at Union College (A.B. 1937) and Columbia University (M.A. 1939. Ph.D. 1945), his professional life encompassed: teaching every public law and government course except constitutional law at Columbia (1942-46); reeducating himself in the new behavioral sciences at Princeton (1946-55); guiding as new colleague and then chairing the innovative political science department at Northwestern (1955-65); contributing briefly as dean and then professor to the new Graduate School of Administration at University of California Irvine (1965-70); and expanding the base and scope of the interdisciplinary Mershon Center at Ohio State (1970-79). He retired in 1979 from the latter institution as director and professor of political science, educational policy and leadership, and public administration emeritus.

He served the APSA as a member of its executive council (1960-62), vice-president (1966-68), and as chair of the committee on pre-collegiate education (1970-77). Among many public services, he was a founder and president of the International Studies Association (197172) and a director of the Foreign Policy Association (1972-76). He lectured at the Foreign Service Institute (1957-59) and at the Army War College (1958-59). He served as consultant to the U.S. Office of Education (1963-65), as codirector of the National Program of Educational Leadership (1970-75), as president of the Civic Education Association (1974-95), and as a director of the Institute for Educational Leadership, Inc. (1980-97). He was a fellow of the Center for Advanced Study in Behavioral Sciences (1956-57) and of the Western Behavioral Sciences Institute (1963-64) and a visiting scholar at the Russell Sage Foundation (1967-68). His publications included The Most Favored Nation Clause (1948), Roots of Political Behavior (1949, coedited with H.H. Wilson), American Foreign Policy (1954, with E.S. Furniss), Role of the Military in American Foreign Policy (1954, with B.M. Sapin), National and International Decision-Making (1961, with J.A. Robinson), and 
Theory and Research on the Causes of War (1969, with Dean Pruitt).

His early Princeton monograph, Decision-Making as an Approach to the Study of International Politics (1954, with H.W. Bruck and B.M. Sapin), was reprinted and expanded with criticisms in Foriegn Policy Decision-Making (1962). It stands as a classic and pioneering example of analytical creativity relevant across a wide spectrum of disciplinary concerns. For Snyder, the heart of politics is the making of human decisions that are embedded in cultural, social, and organizational settings. The hope of humanity lies in improving decision processes. He practiced his own theories of effective decision-making in both personal and professional roles.

Although a leader in the postwar "revolution" to strengthen the scientific foundations of political science, he did not conceive the goal of professional training to be to prepare "value-free" political scientists. In his view, "values can serve as searchlights to spot problems that others without such values cannot see." His own values favored maximum individual autonomy within the context of shared and reciprocal interpersonal responsibilities. He almost always preferred persuasion to coercion.

Dick was a master teacher, supportively evoking creativity in students at every level, welcoming them in first-name relationships and treating them as "junior colleagues." Prolonged conversations often tapped hidden reservoirs of talents and energies. These resulted in lifelong collegiality marked by mutual respect and affection. Yet he did not form a "school," and in fact directed few doctoral dissertations. His goal was not to create disciples but to educate individuals for independent innovation. He labored long over letters of recommendation to make them uniquely descriptive of the special talents of the person introduced. He remained equally dedicated to providing detailed. written comments on the ideas and draft work of friends and colleagues, always with emphasis on the means for further positive development.

He affirmed disciplinary and interdisciplinary cooperation. The jour- nals with which he was intermittently associated--Public Opinion Quarterly, World Politics, and Conflict Resolution-championed such cooperation. No scholar is omnicompetent and everyone need not be a genius. We can advance by "standing on each others' shoulders" and by mutual support of different interests toward overlapping goals. His ability, after silent note-taking in collegial discussions, to identify integrative common concerns that other participants may have overlooked was a rare constructive gift that fellow conferees came to expect at the end of every conference.

Believing that the difficult problems confronting political science require openness to all relevant insights, he pioneered at Northwestern in creating joint appointments with anthropology, psychology, sociology, and law, and recognized the need for one in economics. He came to envision an entire university as a cooperative intellectual enterprise, which he modeled by typically publishing papers and books with coauthors. He sought especially to improve relationships between the social sciences and professional schools, such as education. He had a long-standing interest in improvement of precollegiate political science or civic education.

While supportive of diversity and almost totally devoid of provincial cultural, class, or interest biases, he constantly sought to identify core foundations of shared knowledge that could facilitate community and subsequent specialized innovations. This led, at Northwestern, to an introductory four-course graduate curriculum followed by field specialization, mastery of at least one research method, and a required seminar outside political science. At the University of California, Irvine, it lead to pursuit of a common core curriculum in organizational decision-making that could undergird specialized study in the fields of business, education, and public administration. At Ohio State, Mershon, it led to the innovative National Program in Educational Leadership, the rare Program on Civic Education, the vision of cities as major international actors, the collection and use of systematic social science data, and the diffusion of Harold Lasswell's idea of the decision seminar.

Thereafter, from his home in Scottsdale, he reached out across the frontiers of knowledge as an independent scholar, continuing his extraordinary interdisciplinary readings and extensive note-keeping in the natural sciences, biological sciences, social sciences, religion, humanities, and professions. He continued to serve as creative consultant to private and public projects for the common good, especially in the field of education. Through correspondence (often in long hand), extended telephone conversations, and personal visits, he maintained exchanges of inspiration and ideas with colleagues and former students reaching back over half a century. He remained a persuasive proponent of other people's work to various funding agencies and a generous and confiding friend to colleagues and their families. In every contribution to others during fifty-five years, he benefitted from the partnership of his devoted wife, Marjorie.

Dick Snyder is gone but his legacy of commitment to science, collegiality, and service will endure. For as the Trustees of Ohio State affirmed in their memorial resolution, "Those who considered him their mentor until his death are legion."

Glenn D. Paige
Center for Global Nonviolence
James A. Robinson
University of West Florida

\section{Ronald M. Stout}

Ronald M. Stout, professor emeritus of political science at the State University of New York, Albany, died on February 1, 1998

Born in Indiana, Pennsylvania, he received his B.A., M.A., and $\mathrm{Ph}$. D. degrees from Syracuse University, served in the U S. Army Counterintelligence Corps from 1941 to 1946, and remained in the Army Reserve, retiring as a Lieutenant Colonel in 1979.

He served as an instructor at Syracuse University from 1946 to 1948 when he was appointed an assistant professor at Colgate University. He became a professor at Colgate in 